\title{
Can the prognostic nutritional index be used as an indicator of mortality in patients with acute ischemic stroke?
}

\section{Prognostik nutrisyonel indeks akut iskemik inmeli hastalarda mortaliteyi saptamada bir gösterge olarak kullanılabilir mi?}

Asli Bolayır

Sivas Cumhuriyet Üniversitesi Tip Fakültesi Nöroloji Anabilim Dalı, Sivas,Türkiye

Corresponding author: Aslı Bolayır, MD, Sivas Cumhuriyet Üniversitesi Tıp Fakültesi Nöroloji Anabilim Dalı, Sivas, Türkiye

E-mail: asliarslanturk@gmail.com

Received/Accepted: December 02, 2020 /December 17, 2020

Conflict of interest: There is not a conflict of interest.

\section{SUMMARY}

Objective: It is known that malnutrition in acute ischemic stroke(AIS) patients is closely related to poor prognosis. The clinical and prognostic significance of the prognostic nutritional index (PNI), defined by Onodera et al, in patients with AIS has not yet been exhibited clearly. For this reason, our aim in this study is to determine the effect of PNI on short-term mortality of patients with AIS.

Method: Our study was a single-centered retrospective study. The patient group consisted of 452 patients who were referred to our clinic within the first $24 \mathrm{~h}$ of symptoms and diagnosed with AIS between January 2010-2020. The patient and control groups were compared in terms of albumin, lymphocyte count(LC) and PNI levels.

Results: Albumin, LC and PNI levels were lower in the patient group. Then the patient group was divided into two subgroups according to 30-day mortality [the first group (surviving patients $(n=351)$ ), the second group(exitus within 30 days after AIS $(n=101)$ )]. When these two groups were compared in terms of LC, albumin and PNI levels, the LC, albumin and PNI levels were found lower in the second $\operatorname{group}(\mathrm{p}<0.05)$. A multivariate analysis to determine the risk factors associated with 30-day mortality after AIS revealed that uric acid and PNI were independent variables. Operating characteristic curve analysis also showed that values below 48 for PNI could be used with high sensitivity and specificity in detecting 30-day mortality due to AIS.

Conclusions: This study showed that low PNI levels was closely associated with short-term mortality after AIS. Based on these results, it can be concluded that PNI levels may be regarded as a new indicator for determining post-AIS prognosis. More detailed and extensive prospective studies in this regard are needed in the future.

Keywords: Malnutrition, acute ischemic stroke, mortality, prognostic nutritional index
Asli Bolayır

ORCID IDs of the authors: A.B. 0000-0001-6566-3751 
Amaç: Akut iskemik inmeli(AiIi) hastalarda malnutrisyonun kötü prognozla yakın ilişkili olduğu bilinmektedir. Onodera ve ark. tarafindan tanımlanmış olan prognostik nutrisyonel indeksin(PNI), Aï̇’li hastalardaki klinik ve prognostik önemi net olarak tespit edilememiştir. Bu nedenle bu çalışmadaki amacımız PNI'nin Aili'li hastaların kısa dönem mortaliteleri üzerindeki etkisini ortaya koymaktır.

Yöntem: Çalışmamız tek merkezli retrospektif bir çalışmadır. Hasta grubumuz Ocak 2010- 2020 tarihleri arasında kliniğimize şikayetlerinin başladığı ilk 24 saat içinde başvurmuş ve AïI tanısı kesinleşmiş 452 hastadan oluşmaktadır. Hasta ve kontrol grupları albumin, lenfosit sayısı (LS )ve PNİ düzeyleri açısından kıyaslanmıştır.

Bulgular: Albumin, LS ve PNİ düzeyleri hasta grubunda daha düşük olarak saptandı. Hasta grubu daha sonra 30 günlük mortaliteye göre iki alt gruba ayrıldı[ilk grup(hayatta kalan hastalar(n=351)), ikinci grup (Aİ̇ sonrası 30 gün içinde exitus olanlar ( $\mathrm{n}=101))$ ]. Bu iki grup LS, albumin ve PNİ düzeyleri açısından kıyaslandığında; ikinci grupta LS, albumin ve PNi düzeyleri düşük saptandı. ( $\mathrm{p}<0.05)$ AIİ sonrası 30 günlük mortalite ile ilişkili risk faktörlerini belirlemek için yapılan çok değiş̧kenli analiz ürik asit ve PNI' nin bağımsız değişkenler olduğunu ortaya koydu. Ayrıca işlem karakteristiği eğrisi analizi, PNİ için 48'in altındaki değerlerin AİI'ye bağlı 30 günlük mortaliteyi saptamada yüksek duyarlılık ve seçicilik ile kullanılabileceğini gösterdi.

Sonuç: Bu çalışma düşük PNİ seviyelerinin AIII sonrası kısa dönem mortalite ile yakın ilişkili olduğunu saptamıștır. Bu sonuçlara dayanarak, PNİ düzeylerinin AIİ sonrası prognozu belirlemede yeni bir gösterge olarak kabul edilebileceği söylenebilir. Bu konuda gelecekte daha detaylı ve geniş prospektif çalışmalara ihtiyaç vardır.

Anahtar sözcükler: Malnutrisyon, akut iskemik inme, mortalite, prognostik nutrisyonel indeks

\section{INTRODUCTION}

The socioeconomic importance of stroke in populations is gradually increasing. In accordance with the data of the World Health Organization, cerebrovascular diseases are in the second place among all causes of death. Acute ischemic stroke (AIS) accounts for approximately $60-80 \%$ of all cerebrovascular diseases. The rate of developing nutritional deficiency is quite high after AIS with high mortality and morbidity rates ${ }^{1}$. It is a known fact that malnutrition in AIS patients is closely associated with poor prognosis ${ }^{2}$. However, there are no data about the prognosis of patients with nutritional deficiency before the development of AIS.

Serum albumin concentration and lymphocyte count (LC), which can also be affected by other non-nutritional factors, including inflammation and stress, represent traditional criteria utilized to demonstrate nutritional status ${ }^{3-7}$. The prognostic nutritional index (PNI), which was defined by Onodera et al., combines the information obtained from the mentioned two criteria and is computed using the formula of $\mathrm{PNI}=$ serum albumin $(\mathrm{g} / \mathrm{l})+$ $\left(5 \times \mathrm{LC}\left(\times 10^{9} / \mathrm{l}\right)\right)^{8}$. It has been demonstrated that the simple indirect calculation in question, which provides information on immunocompetence, inflammation, and nutritional status, may be utilized to predict survival rates in a large number of malignancies ${ }^{9-14}$. Nevertheless, the clinical and prognostic importance of the PNI value in AIS patients has not been revealed yet. Therefore, we aimed in the present research to identify the impact of the PNI value measured in the acute period on the short-term mortality of AIS patients.

\section{MATERIAL AND METHODS}

\section{Study Group:}

The current research is a single-center retrospective study. Our patient group consists of 452 patients who applied to our clinic within the first 24 hours of their complaints between January 2010 and January 2020 and in whom the diagnosis of AIS was confirmed.

The patient's history in confirming the diagnosis of AIS, the presence of newly developed neurological deficit (hemiparesis/hemiplegia, hemihypesthesia, aphasia/dysphasia/dysarthria, ataxia, nystagmus ...) in the neurological examination and the presence of newly developed ischemic lesions in brain imaging (cranial magnetic resonance imaging or computerized brain tomography) and the exclusion of other diagnoses (intracranial spaceoccupying formation, intracerebral hemorrhage, post-seizure condition...) that might lead to similar neurological examination or brain imaging findings were taken as a basis. No restrictions were made among the patients in terms of age and sex. Then, the patient group was separated into two subgroups in accordance with 30-day mortality. While the first group patients survived, the second group patients died within 30 days.

Our exclusion criteria are being younger than 18 years of age, a history of infection within two weeks prior to admission or a history of acute coronary syndrome in the last three months, the presence of chronic connective tissue disease or systemic acute/chronic inflammatory/autoimmune disease, having hematological disorder, cancer, severe liver, renal, or heart failure, and a history of 
major surgery or trauma in the last month, alcoholism, or the use of immunosuppressants or anti-inflammatory drugs or steroids in the last three months.

Four hundred fifty controls of similar age and gender who gave blood for other reasons in the same date range were also included in our patient group. The patients in our control group did not have any uncontrolled systemic disease.

All volunteers included in our study were also evaluated for albumin, LS and PNI levels apart from some baseline demographic characteristics and laboratory parameters such as age, sex, the presence of diabetes mellitus (fasting blood glucose above $126 \mathrm{mg} / \mathrm{dl}$ or antidiabetic drug use), hypertension (systolic blood pressure higher than $140 \mathrm{mmHg}$ and/or diastolic blood pressure higher than $90 \mathrm{mmHg}$ ), hyperlipidemia (the fasting total cholesterol value higher than $200 \mathrm{mg} / \mathrm{dl}$ and/or triglyceride value higher than $150 \mathrm{mg} / \mathrm{dl}$ [National Cholesterol Education Program Adult Treatment Panel III guideline], a history of smoking (being a smoker or quitting in the last six months), the use of statins, serum glucose, creatinine, uric acid, Creactive protein, total cholesterol, low-density lipoprotein (LDL), high-density lipoprotein (HDL), triglyceride, hemoglobin, white blood cell (WBC), monocyte and neutrophil counts.

Incomplete information in relation to our study was obtained from the phone calls made with our patients or their relatives.

\section{Evaluation of Biochemical and Hematological Data:}

Blood samples were taken from the patients from the right antecubital vein within the first 24 hours after AIS. Dry tubes were utilized for biochemical analysis, while EDTA tubes were utilized for hematological testing. While the complete blood count parameters of the patient and control groups were measured using Diagon kits in the Mindray BC-6800 device, the Beckman Coulter AU5800 (Beckman Coulter Inc, Hialeah, Florida) device and kits of the same company were used for biochemical analysis. PNI values were computed using the formula of $\mathrm{PNI}=\operatorname{serum}$ albumin $(\mathrm{g} / \mathrm{l})+$ $\left(5 \times \operatorname{LC}\left(\times 10^{9} / 1\right)\right)$.

\section{Statistical Method:}

The data acquired from the present research were assessed by utilizing the SPSS 22.0 program. Continuous data were presented as mean \pm standard deviation and median (min-max), while categorical data were expressed as percentage (\%). The Kolmogorov-Smirnov test was conducted for the purpose of determining normal distribution. Since the continuous data obtained from two different groups in our study were not normally distributed, the Mann-Whitney $U$ test was performed for analysis. While logistic regression analysis was conducted for the purpose of determining risk factors in 30-day mortality of AIS patients, the process characteristic curve analysis was conducted to find the best cut-off point of the PNI value. The values of $p<0.05$ were considered to be statistically significant.

\section{RESULTS}

When the patient and control groups were compared concerning baseline demographic characteristics, no difference was determined between the two groups in terms of age, sex, the presence of diabetes mellitus and hypertension, and the usage of statins and smoking. While the average age in the patient group was $78.92 \pm 7.1$ years, it was $79.01 \pm 6.2$ years in the control group. When the laboratory parameters were examined, no significant difference was found between the two groups concerning glucose, creatinine, hemoglobin, HDL, LDL, and total cholesterol levels $(\mathrm{p}=0.06, \mathrm{p}=0.11, \mathrm{p}=0.47, \mathrm{p}=0.09, \mathrm{p}=0.07$, and $\mathrm{p}=0.36$ ). Furthermore, while uric acid, $\mathrm{C}$ reactive protein, and white blood cell counts were high in the patient group, albumin, LS, and PNI levels were detected to be high in the control group (Table 1).

Afterward, the patient group was separated into two subgroups in accordance with 30-day mortality. While there were surviving patients in the first group $(\mathrm{n}=297)$, the second group patients died within 30 days following AIS $(n=87)$. When the said two groups were compared for LS, albumin, and PNI levels, LS, albumin, and PNI levels were detected to be statistically significantly lower in the second group $(\mathrm{p}<0.05)$ (Table 2).

The multivariate analysis performed for the purpose of determining risk factors related to 30day mortality following AIS showed that uric acid, CRP, and PNI were independent variables (Table $3)$. 
Table 1: Comparison of the basal demographic characteristics and laboratory parameters of the patient and control groups

\begin{tabular}{|c|c|c|c|c|c|}
\hline \multirow{2}{*}{\multicolumn{2}{|c|}{$\operatorname{Age}(\operatorname{mean} \pm \operatorname{SD})(\min -\max )$}} & AIS group $(n=452)$ & Control group $(n=450)$ & $\mathrm{X}^{2}$ & $\mathbf{p}$ \\
\hline & & $\begin{array}{c}78.92 \pm 7.1 \\
(62-97)\end{array}$ & $\begin{array}{c}79.01 \pm 6.2 \\
(66-95)\end{array}$ & & 0.38 \\
\hline Gender, $\mathbf{n}(\%)^{* *}$ & $\begin{array}{r}\text { Female } \\
\text { Male }\end{array}$ & $\begin{array}{l}225(49.7) \\
227(50.3)\end{array}$ & $\begin{array}{l}235(50.4) \\
215(49.6)\end{array}$ & 0.01 & 0.93 \\
\hline \multicolumn{2}{|l|}{ HT, n (\%) $)^{* *}$} & $308(68.1)$ & $288(64.0)$ & 2.71 & 0.82 \\
\hline \multicolumn{2}{|l|}{ DM, n $(\%)^{* *}$} & $121(26.8)$ & $142(31.5)$ & 1.23 & 0.35 \\
\hline \multicolumn{2}{|c|}{ Smoking, n (\%) ${ }^{* *}$} & $137(30.3)$ & $161(35.7)$ & 3.24 & 0.11 \\
\hline \multicolumn{2}{|c|}{ Statine use, $\mathbf{n}(\%)^{* * *}$} & $187(41.3)$ & $203(45.1)$ & 0.54 & 0.08 \\
\hline \multicolumn{2}{|c|}{ TotalKol(mg/dL) $($ mean \pm SD) } & $181.22 \pm 49.53$ & $178.74 \pm 38.13$ & & 0.36 \\
\hline \multicolumn{2}{|c|}{ LDL $(\mathrm{mg} / \mathrm{dL})(\mathrm{mean} \pm \mathrm{SD})$} & $127.01 \pm 7.73$ & $108.17 \pm 7.51$ & & 0.07 \\
\hline \multicolumn{2}{|c|}{ HDL $(\mathrm{mg} / \mathrm{dL})($ mean \pm SD $)$} & $42.93 \pm 25.61$ & $49.81 \pm 18.96$ & & 0.09 \\
\hline \multicolumn{2}{|c|}{$\operatorname{Uric} \operatorname{acid}(m g / d L)($ mean \pm SD $)$} & $6.55 \pm 1.32$ & $4.21 \pm 0.71$ & & $<0.001$ \\
\hline \multicolumn{2}{|c|}{ Creatinine (mg/dL) (median)(min-max) } & $\begin{array}{c}0.79 \\
(0.58-1.2)\end{array}$ & $\begin{array}{c}0.81 \\
(0.57-1.3)\end{array}$ & & 0.11 \\
\hline \multicolumn{2}{|c|}{ Glucose (mg/dL) (median)(min-max) } & $\begin{array}{c}149.53 \\
(78-225)\end{array}$ & $\begin{array}{c}121.43 \\
(72-212)\end{array}$ & & 0.06 \\
\hline \multicolumn{2}{|c|}{$\mathrm{Hb}(\mathrm{g} / \mathrm{dL})($ median$)(\min -\mathrm{max})$} & $\begin{array}{c}14.24 \\
(7.9-18.9)\end{array}$ & $\begin{array}{c}14.33 \\
(10.1-17.6)\end{array}$ & & 0.47 \\
\hline \multicolumn{2}{|c|}{$C R P(m g / d L)($ mean $\pm S D)$} & $16.28 \pm 7.35$ & $5.26 \pm 3.11$ & & $<0.001$ \\
\hline \multicolumn{2}{|c|}{ White blood cell caount $\left(10^{3} / \mathrm{mm}^{3}\right)($ mean $\pm S D)$} & $9460.24 \pm 3712.09$ & $6528.36 \pm 1937.20$ & & $<0.001$ \\
\hline \multicolumn{2}{|c|}{$\mathrm{NC}\left(10^{9} / \mathrm{ml}\right)($ mean $\pm \mathrm{SD})$} & $4520.04 \pm 3474.70$ & $4737.06 \pm 1265.08$ & & 0.12 \\
\hline \multicolumn{2}{|c|}{$\operatorname{MC}\left(10^{9} / \mathrm{ml}\right)($ ort $\pm S S)$} & $518.04 \pm 261.34$ & $501.49 \pm 93.20$ & & 0.24 \\
\hline \multicolumn{2}{|c|}{$L C\left(10^{9} / m l\right)(($ mean $\pm S D)$} & $1125.33 \pm 705.29$ & $1893.28 \pm 520.08$ & & 0.02 \\
\hline \multicolumn{2}{|c|}{$\operatorname{Albumin}(g / l)($ median$)($ min-max $)$} & $34(14-46)$ & $55(42-55)$ & & $<0.001$ \\
\hline \multicolumn{2}{|c|}{$P N I($ mean $\pm S D)($ min-max $)$} & $\begin{array}{c}51.31 \\
(44.6-55.5)\end{array}$ & $\begin{array}{c}64.78 \\
(50.3-62.7)\end{array}$ & & 0.03 \\
\hline
\end{tabular}

Abbreviations: CRP: C-reactive protein; DM: diabetes mellitus; Hb: hemoglobin; HDL: high density lipoprotein; HT: hypertension; LDL: low density lipoprotein; LC: lymphocyte count; MC: monocyte count; NC: neutrophil count; PNI: prognostic nutritional index, Totalkol: total cholesterol; SD: standard deviation.

Table 2: Comparison of lymphocyte count, albumin and PNI values of surviving and non-surviving patients in the patient group.

\begin{tabular}{|l|l|l|l|}
\hline & Surviving patients $(\mathbf{n}=351)$ & $\begin{array}{l}\text { Non-surviving patients } \\
(\mathbf{n = 1 0 1})\end{array}$ & $\mathbf{p}$ \\
\hline LC $(\mathbf{1 0} 9 / \mathbf{m l})($ mean \pm SD) & $1156.94 \pm 402.31$ & $1014.33 \pm 302.84$ & 0.04 \\
\hline Albumin $($ g/l $)($ median) (min-max) & $36.18(14-46)$ & $26.41(34-41)$ & 0.02 \\
\hline PNI (mean \pm SD)(min-max) & $52.97(53.4-55.5)$ & $48.22(44.6-49.3)$ & 0.03 \\
\hline
\end{tabular}

Abbreviations: LC: lymphocyte count; PNI: prognostic nutritional index; SD: standard deviation.

Table 3: Logistic regression analysis of independent significant variables in 30-day mortality related to AIS.

\begin{tabular}{|l|l|l|l|l|l|}
\hline & $\mathbf{B}$ & SS & $\mathbf{p}$ & $\mathbf{E x p}(\mathbf{B})$ & $\mathbf{9 5 \%}$ CI \\
\hline Uric acid & 2.53 & 0.67 & 0.001 & 12.68 & $3.45-52.55$ \\
\hline CRP & 0.62 & 0.17 & 0.001 & 1.78 & $1.31-2.67$ \\
\hline PNI & 1.65 & 0.42 & 0.001 & 6.23 & $2.82-14.01$ \\
\hline
\end{tabular}

Abbreviations: CRP: C-reactive protein, CI: confidence interval, PNI: prognostic nutritional index, SD: standard deviation, $\beta$ : regression coefficient.

Furthermore, the process characteristic curve analysis demonstrated that values lower than $\mathbf{4 8 . 1 2}$ for PNI could be utilized with high sensitivity and specificity to detect 30-day mortality due to AIS
(Area under the curve (AUC): 0.76, 95\% confidence interval (CI): 0.66-0.87, sensitivity: $73.1 \%$, specificity: $81.1 \%$ ) (Figure 1). 


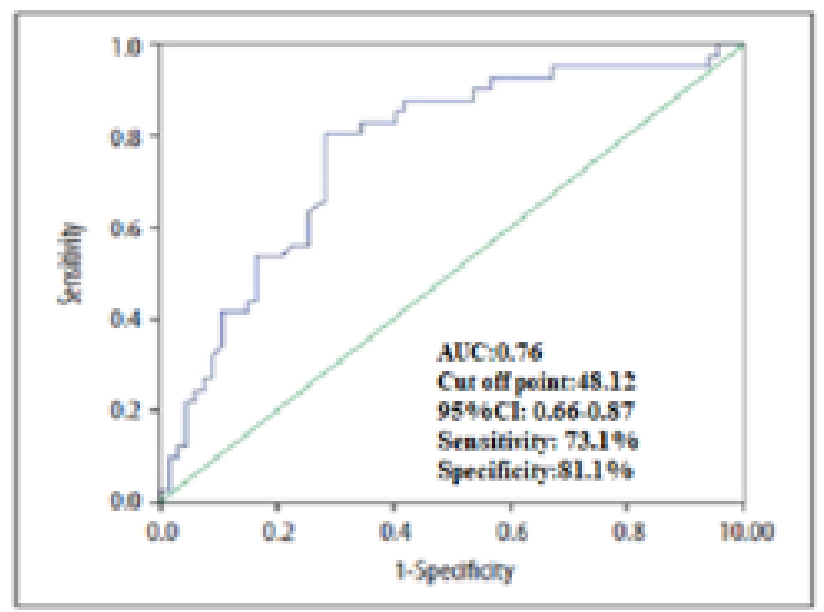

Figure 1: Receiver Operating Characteristic(ROC) curve analysis for PNI value.

\section{DISCUSSION}

Malnutrition can be defined as all changes in the body due to insufficient nutrition or diseases. Despite advancements in the field of healthcare, malnutrition continues to be an important and common health problem even in developed countries.

The Clinical Enteral Parenteral Nutrition Association (KEPAN), the only national association related to nutritional support, conducted a six-month study in 34 centers in 19 cities in 2005-2006 to see the situation in Turkey 14. According to the result of this study, malnutrition is more common $(50-70 \%)$ in the elderly patient group, while this rate is around 55$65 \%$ in patients with neurological disease.

As is known, one of the main effects of malnutrition is on the immune system. Lymphatic tissues are atrophied, cellular immunity is impaired, and bactericidal leukocyte activity is reduced in patients with malnutrition. During fasting, the main defect in the immune system is in T-lymphocytes and the complement system. Lymphocytes in the thymus are damaged, and the thymus undergoes atrophy. Interleukin (IL) metabolism, especially IL-1 activity, is suppressed. Impaired IL-1 activity leads to a decrease in the rate of lymphocyte production, resulting in a decrease in lymphocyte count ${ }^{15}$. In our study, in line with these results, a lower PNI value was found in the patient group with malnutrition, in other words, a lower LS value.

A parameter that can evaluate the nutritional status from all aspects has not been developed yet. To this end, PNI, developed by Onodera et al., is computed using the formula of serum albumin $(\mathrm{g} / \mathrm{l})+(5 \times \mathrm{LC}$ $\left.\left(\times 10^{9} / 1\right)\right)$. It is accepted that the PNI value reflects the inflammatory, nutritional, and immune status in oncological patients, and it was found to have prognostic significance in many malignant neoplastic diseases [8-13]. In this patient group, it was determined that PNI below 40 predicts the risk of complications, sepsis, and death with $90 \%$ reliability.

However, the PNI value is closely related to the serum albumin level, as mentioned before. Albumin has a long metabolic half-life of 18-20 days, so it takes a long time for its level to decrease in cases of malnutrition. Nevertheless, in our study, measurements were made within the first 24 hours after AIS in patients. Therefore, these measurements reflect the pre-AIS malnutrition rather than malnutrition developing after AIS. Based on this, it can be said that these measurements made in the present study were performed to evaluate mortality in patients with malnutrition before AIS. Based on the results of our study, it can be said that the prognosis will be much poorer and mortality will be much higher after AIS in patients with malnutrition before the development of AIS. Furthermore, similar to the study conducted by Xiang et al., we revealed that low PNI value in the acute period was associated with mortality in AIS patients ${ }^{16}$. Therefore, measuring the PNI value, which can be easily calculated and does not require additional expenses, in the acute period can be used to determine the short-term prognosis in these patients. Moreover, the close monitoring of the nutrition of patients with low PNI values and 
providing the necessary nutritional support to these patients may decrease the 30-day mortality rates of these patients after AIS.

The present research has various limitations. First, the current research is a single-center retrospective study. Therefore, the number of patients is low to make more interpretations. Moreover, only the PNI value was used to evaluate malnutrition; the other parameters and ratios used to evaluate nutrition (such as the CONUT (Controlling nutritional status) score, body mass index, and total cholesterol) were not evaluated. In addition, the clinical (such as the modified Rankin score (mRS) or the National Institutes of Health Stroke Scale (NIHSS)) or radiological correlation of the PNI value in patients was not evaluated.

\section{CONCLUSION}

In this study, we revealed that AIS patients had lower LS, albumin, and PNI levels in the acute period compared to controls of similar age and sex, and these low PNI levels were closely related to short-term mortality following AIS. According to the mentioned results, it is possible to say that PNI levels in the acute period can be accepted to be a new indicator in determining the short-term prognosis after AIS. There is a need for more detailed and extensive prospective studies on this issue.

Footnote: Some of the data of this study were presented as oral presentation( OP-158) at the SANAR(1st International Congress On Sports, Anthropology, Nutrition, Anatomy And Radiology) congress in 2018.

\section{REFERENCES}

1. Miller EL, Murray L, Richards L, Zorowitz RD, Bakas T, Clark P, Billinger SA. Comprehensive overview of nursing and interdisciplinary rehabilitation care of the stroke patient: a scientific statement from the American Heart Association. Stroke 2010; 41(10): 2402-48.

2. Ryu WS, Lee SH, Kim CK, Kim BJ, Yoon BW. Body mass index, initial neurological severity and long-term mortality in ischemic stroke. Cerebrovascular Diseases 2011; 32(2): 170-6.

3. Fock RA, Blatt SL, Beutler B, Pereira J, Tsujita M, de Barros FEV, Borelli P. Study of lymphocyte subpopulations in bone marrow in a model of protein-energy malnutrition. Nutrition 2010; 26(10): 1021-8.

4. Rocha NP, Fortes RC. Total lymphocyte count and serum albumin as predictors of nutritional risk in surgical patients. ABCD. Arquivos Brasileiros de Cirurgia Digestiva (São Paulo)2015; 28(3): 193-6.

5. Zhang Z, Pereira SL, Luo M, Matheson EM. Evaluation of blood biomarkers associated with risk of malnutrition in older adults: A systematic review and meta-analysis. Nutrients 2017; 9(8):829.

6. Blackburn GL, Bistrian BR, Maini BS, Schlamm HT, Smith MF. Nutritional and metabolic assessment of the hospitalized patient. Journal of parenteral and enteral nutrition 1977; 1(1): 11-21.

7. Onodera T, Goseki N, Kosaki G. Prognostic nutritional index in gastrointestinal surgery of malnourished cancer patients. Nihon Geka Gakkai Zasshi 1984; 85(9);1001-5.

8. Periša V, Zibar L, Knezović A, Periša I, SinčićPetričević J, Aurer I. Prognostic nutritional index as a predictor of prognosis in patients with diffuse large B cell lymphoma. Wiener klinische Wochenschrift 2017; 129(11-12):4119.

9. Sun K, Chen S, Xu J, Li G, He Y. The prognostic significance of the prognostic nutritional index in cancer: a systematic review and meta-analysis. Journal of cancer research and clinical oncology 2014; 140(9): 1537-49.

10. Okada S, Shimada J, Kato D, Tsunezuka $\mathrm{H}$, Teramukai S, Inoue M. Clinical significance of prognostic nutritional index after surgical treatment in lung cancer. The Annals of thoracic surgery 2017; 104(1): 296-302.

11. Yang Y, Gao P, Chen X, Song Y, Shi J, Zhao J, Wang Z. Prognostic significance of preoperative prognostic nutritional index in colorectal cancer: results from a retrospective cohort study and a meta-analysis. Oncotarget 2016;7(36): 58543.

12. Lee JY, Kim HI, Kim YN, Hong JH, Alshomimi S, An JY, Kim CB. Clinical significance of the prognostic nutritional index for predicting short-and long-term surgical outcomes after gastrectomy: a retrospective analysis of 7781 gastric cancer patients. Medicine 2016; 95(18).

13. Lee SH, Chung MJ, Kim B, Lee HS, Lee HJ, Heo, JY, Song SY. The Significance of the Prognostic Nutritional Index for All Stages of Pancreatic Cancer. Nutrition and cancer 2017; 69(3):512-9. 
14. Korfali G, Gündoğdu H, Aydintug S, Bahar M, Besler T, Moral AR. (2009). Nutritional risk of hospitalized patients in Turkey. Clin Nutr 2009; 28: 533-7.

15. Meakins J. Therapeutic approaches to anergy in surgical patients: Surgery and levamisole. Ann Surg 1979; 190: 286-8.
16. Xiang W, Chen X, Ye W, Li J, Zhang X, Xie D. Prognostic nutritional index for predicting 3-month outcomes in ischemic stroke patients undergoing thrombolysis. Frontiers in Neurology 2020; 11: 599-603. 